\title{
Lumen
}

Selected Proceedings from the Canadian Society for Eighteenth-Century Studies

\section{Providence, Indigenous Protagonism, and Enlightenment: Clavijero's Rendition of the Conquest of México}

\section{Beatriz de Alba-Koch}

Volume 24, 2005

Indigenes and Exoticism

Indigènes et exotisme

URI : https://id.erudit.org/iderudit/1012174ar

DOI : https://doi.org/10.7202/1012174ar

Aller au sommaire du numéro

Éditeur(s)

Canadian Society for Eighteenth-Century Studies / Société canadienne d'étude du dix-huitième siècle

ISSN

1209-3696 (imprimé)

1927-8284 (numérique)

Découvrir la revue

Citer cet article

de Alba-Koch, B. (2005). Providence, Indigenous Protagonism, and

Enlightenment: Clavijero's Rendition of the Conquest of México. Lumen, 24,

49-63. https://doi.org/10.7202/1012174ar

Copyright (c) Canadian Society for Eighteenth-Century Studies / Sociéte canadienne d'étude du dix-huitième siècle, 2005
Ce document est protégé par la loi sur le droit d'auteur. L'utilisation des services d'Érudit (y compris la reproduction) est assujettie à sa politique d'utilisation que vous pouvez consulter en ligne.

https://apropos.erudit.org/fr/usagers/politique-dutilisation/ 


\section{Providence, Indigenous Protagonism, and Enlightenment: Clavijero's Rendition of the Conquest of México}

I have made truth my main goal. ... But to me, enemy of all deceit, lie and affectation, it seems that the truth is that much more beautiful when it is more naked. ... In sum, I have always been mindful of those two holy laws of history: not to dare say a lie nor to be afraid of saying the truth, and I believe I have not broken them. ${ }^{1}$

This appreciation of truth was penned by Francisco Javier Clavijero (1731-1787), a Creole Jesuit of New Spain, who from exile in the Papal States wrote the monumental Historia antigua de México, one of the most important works of the Latin American Enlightenment. Considering the task 'no less fatiguing and difficult than expensive,' Clavijero stated that he wrote the Historia with three goals in mind: '[T]o evade the fastidious and reprehensible leisure to which I have been condemned, to serve in the best possible manner my patria, [and] to restore to its splendor the truth, obfuscated by an incredible mob of modern writers on America. ${ }^{2}$ Without having left their studies at Berlin, Edinburgh, and Paris, and more dedicated to insisting on the importance of their homelands than dispassionate scholarly study, several writers widely accepted as leading figures of the Enlightenment - George-Louis Leclerc Buffon, Cornelius de Pauw, Guillaume-Thomas Raynal, and William Robertson prominent among them - had embarked on a comprehensive denigration of the New World. These men articulated a racist vision which claimed that America was hobbled by an immature geography, insalubrious climate, fauna and flora lacking in size and variety, and a weak,

1 Francisco Xavier Clavijero, Historia antigua de México, ed. Mariano Cuevas (México: Porrúa, 1945), xxii. Unless otherwise indicated, all translations from the Spanish are the work of the present author.

2 Ibid., xxi. 
infertile native population, incapable of developing abstract ideas and in every respect inferior to Europeans. The innate weakness of America was held by Raynal's editorially complex Histoire des Deux Indes to be contagious to whoever came into contact with the hemisphere. ${ }^{3}$ In contesting this portrayal of America, Clavijero focused on the Conquest of México, as for him the true nature of its inhabitants could there be seen in action. In his account of the fall of Tenochtitlán, Clavijero presented the diverging evidence regarding that controversial event in a manner that exemplified the epistemological expectations of the Enlightenment. However, that providence was for him the determining factor in the outcome of the Spanish invasion underlines his strong commitment to a Christian view of history. A close scrutiny of how Clavijero dealt with the demise of the ancient Mexicans is key to our understanding of the complexities of the Latin American Enlightenment.

The thesis of the weakness and immaturity of the American continent was first developed by Buffon in the context of his attempt to come to an understanding of natural phenomena and differences amongst humankind independent of biblical authority. For him, the particularities of a natural environment shaped the organisms living within it. Thus the inhabitants of America were described as enfeebled by the humidity of their climate:

3 The most comprehensive account of the Enlightenment debate on the nature of America is the revised and expanded translation of Antonello Gerbi's landmark study, La disputa del Nuevo Mundo: Historia de una polémica 1750-1900, ed. and trans. Antonio Alatorre (México: Fondo de Cultura Económica, 1993); for Gerbi's discussion of Clavijero, see 245-65. Gerbi first published his work as La disputa del Nuovo Mondo in 1955. A recent reconsideration of this debate is provided by Jorge Cañizares-Esguerra, How to Write the History of the New World: Historiographies, Epistemologies, and Identities in the Eighteenth-Century Atlantic World (Stanford: Stanford University Press, 2001); for Cañizares-Esguerra's more complex view of Clavijero's reaction to European scholars, see 234-49. For Clavijero as Creole patriot, see David Brading, The First America: The Spanish Monarchy, Creole Patriots, and the Liberal State 1492-1867 (Cambridge: Cambridge University Press, 1991), 450-62. An insightful discussion of the impact in Spanish America of the works of Roberston and Raynal is provided by Brading, 422-46. For a discussion of Clavijero's rebuttal of Spanish and Novohispano contempt for indigenous languages, see Dorothy Tanck de Estrada, 'Clavijero: Defensor de los idiomas indígenas frente al desprecio europeo,' in Francisco Xavier Clavijero en la Ilustración mexicana 1731-1787, ed. Alfonso Martínez Rosales (México: Colegio de México, 1988), 23-30. 
Le sauvage est foible et petit par les organes de la génération; il n'a ni poil ni barbe, et nulle ardeur pour sa femelle: quoique plus léger que l'Européen, parce qu'il a plus d'habitude à courir, il est cependant beaucoup moins fort de corps; il est aussi bien moins sensible, et cependant plus craintif et plus lâche; il n'a nulle vivacité, nulle activité dans l'âme; celle du corps est moins un exercice, un mouvement volontaire, qu'une nécessité d'action causée par le besoin; ôtez-lui la faim et la soif, vous détruirez en même temps le principe actif de tous ses mouvements; il demeurera stupidement en repos sur ses jambes ou couché pendant des jours entiers. ${ }^{4}$

Buffon set in motion a discursive practice which was to have numerous exponents. A yet more categorical expression of the inferiority of the American peoples was to be found in de Pauw's 1768 Recherches philosophiques sur les Américains.

Authors such as de Pauw and Robertson insisted that their portrayal of the New World was based on reliable empirical evidence; thus de Pauw announced that he had 'relied on facts as [his] only witnesses.' However, these authors based their work on the accounts of recent travellers whom they felt were sufficiently enlightened to provide reliable information, and not on their own observations; they discounted indigenous testimony as wanting in analytical rigour. Understandably, their approach provoked outrage and incredulity amongst scholars of the Americas. Their disdain for Hispanic and indigenous sources clashed with what Jorge Cañizares-Esguerra has called the 'patriotic epistemol-

4 Cited in Gerbi, 10. Buffon utilized 'race' as a classifying concept 'au sens moderne de subdivision de l'espèce humaine' in his 1749 essay, 'Variétés dans l'espèce humaine,' in L'idée de 'race' dans les sciences humaines et la littérature, ed. Sarga Moussa (Paris: L'Harmattan, 2003), 8. For Buffon, the Sami and other northernmost inhabitants of the globe, including the 'savages' which he believed inhabited a region north of the Inuit, constituted 'la même race,' which he described as 'bien différente des autres: il semble que se soit une espèce particulière dont tous les individus ne sont que des avortons; car s'il y a des différences parmi ces peuples, elles ne tombent que sur le plus ou le moins de difformité' (Buffon, De l'homme, ed. Michèle Duchet [Paris: Maspero, 1971], 224).

5 However, by 1777 Buffon had become better informed about Prehispanic antiquities. In an 'Addition' to the 'Variétés dans l'espèce humaine,' he chastised de Pauw for negating the existence of the 'monuments des Méxicains et des Péruviens,' whose remains 'démontrent la grandeur et le génie de ces peuples, qu'il traite comme des êtres stupides, dégénerés de l'espèce humaine, tant pour le corps que pour l'entendement' (Buffon, 371).

6 Cañizares-Esguerra, 45, 51-53. 
ogy' of learned Latin American Creole clerics, of whom Clavijero was one of the most prominent Novohispano representatives. ${ }^{7}$ The Creole patriots were proud of the achievements of the Prehispanic Mexica and Inka; they were convinced that the indigenous aristocracies should be accorded the same respect as European nobles. This solicitude for the former rulers of Cuzco and Tenochtitlán, however, was not predicated on a comprehensive rejection of conventional European conceptions of social hierarchy and its racist justifications. The Creole patriots, themselves the descendants of European invaders and immigrants, although committed to maintaining their social privileges, were concerned about the plight of their commoner indigenous contemporaries. Clavijero deplored the circumstances to which the Amerindians had been reduced, lamenting that their schooling was neglected and observing that it is difficult, if not impossible, to progress in the sciences in the midst of a miserable, servile, and continually uncomfortable existence.' He argued that the economy of New Spain depended entirely on the indigenous population, as 'they carry the weight of all public works' with the exception of the production of tobacco and sugar, which Clavijero contended was cultivated principally by Africans. ${ }^{8}$

As orthodox Catholics, these Creole scholars were disinclined to reject information accumulated by studious monks of the sixteenth and seventeenth centuries. Clavijero saw no contradiction in combining Enlightenment empiricism with a respect for the erudition of the religious orders: he subjected the compilations, chronicles, and histories assembled by soldiers, friars, and other clerics to critical scrutiny, but also ascribed an important role to providence in his account of the Conquest. In reconciling his faith in providence with his determination to apply rigourously critical standards to the study of history, he may have found a helpful guide in the scholarship of Giambattista Vico.

Clavijero distinguished himself amongst the scholars who came to the defense of America because of his prolonged personal contact with the indigenous peoples of New Spain. Born in Veracruz in 1731, he became a Jesuit in 1748, perfecting his knowledge of Nahuatl after he joined the order. ${ }^{9}$ By 1768 Clavijero was installed at Bologna, where he was to

7 Ibid., 13-15, 18, 204-65.

8 Clavijero, 510, 518.

9 For biographical information on Clavijero, see José Mariano Beristáin de Souza, Biblioteca Hispano-Americana Septentrional (México: Calle de Santo Domingo y Esquina de Tacuba, 1816), 1:353-7; Luis González y González, Obras completas (México: Clío, 
remain until his death in 1787. In 1779 he finished his Historia, a work which he was obliged to translate into Italian for publication due to what Mariano Beristáin de Souza called 'political reasons. ${ }^{10}$ The first three volumes of what had become the Storia antica del Messico appeared at Cesena in 1780; the fourth appeared the following year. Translations into English, German, and French followed, fostering public interest in Mexican archaeology on both sides of the Atlantic. However, Clavijero's admiration for some aspects of Prehispanic culture, his critical view of Hernán Cortés, and his denunciation of the oppression of New Spain's indigenous population, which he compared to that of the Greeks under the Ottoman empire, were read as an attack on the Spanish regime. ${ }^{11}$ Nonetheless, by the middle of the nineteenth century, he was being read as an advocate of independence, and has since been commonly considered a father of Mexican nationalism. ${ }^{12}$

Clavijero combined a natural history of New Spain, a description of its fauna and flora, with an 'ancient' history of its dominant indigenous ethnic group, called Aztecs here for the first time. ${ }^{13}$ A detailed and vivid narration of the conquest of México closed his account and was followed by nine 'dissertations' which constituted a sustained and carefully argued refutation of the detraction of America. While in the natural and ancient history the debate with his opponents was relegated to his extensive footnotes, in the dissertations he rebuffed with passion the 'bufonadas' with which de Pauw painted his 'monstrous portrait' of a degenerate America. Clavijero announced that he would focus on the

1995), 2:111-29; and Charles E. Ronan, S. J., Francisco Javier Clavigero, S. J. (Roma: Institutum Historicum, 1977). Beristáin claimed that Clavijero was versed in Mixtec and Otomí, adding that he also had an understanding of some further twenty indigenous languages. See Beristain de Souza, 1:354.

10 Beristáin de Souza, 1:355.

11 In 1784 the Catalan Jesuit, Ramón Diosdado Caballero, actively campaigned against the plans to publish the Storia in Spanish by producing 'three volumes of "observations," now lost, in which he refuted many of the points made by Clavijero on the alleged grandeur of the Mesoamerican past' (Cañizares-Esguerra, 187). For a detailed account of this intrigue and the extensive red tape it produced within the Spanish bureaucracy, see Ronan, 154-79. The first publication of Clavijero's original text in Spanish did not appear until 1945.

12 González y González, 1:111-4, 125, 128-9 and Jacques Lafaye, Quetzalcóatl y Guadalupe: La formación de la conciencia nacional en México, trans. Ida Vitale and Fulgencio López Vidarte (México: Fondo de Cultura Económica, 1977), 172-5.

13 Hugh Thomas, Conquest: Montezuma, Cortés, and the Fall of Old Mexico (New York: Simon and Schuster, 1993), xixn1. 
work of de Pauw because 'as in a bilge or sewer, [de Pauw] has gathered all the offal, that is, all the errors of those who preceded him. If my expressions appear to be a little strong,' he added, 'it is because one need not be gentle with a man who insults the entire New World and the most respectable figures of the Old World. ${ }^{14}$ However, Clavijero no less than his opponents was convinced of the value of rationalism and empiricism, and thus confronted these leading figures of the European Enlightenment on their terms, contending that their claims were neither supported by a careful consideration of a wide array of sources nor by first-hand observations.

For Clavijero, the attitude of de Pauw, Robertson, and Raynal was typical of the spirit of his century, which he saw as inclined to cover irreverence with the mantle of erudition. He claimed that the eighteenth century was the one 'in which more errors have been published than in all the previous centuries, in which [authors] write with liberty, lie without shame, and he who is not a philosopher is not appreciated, nor reputed as such he who does not parody religion and adopt the language of impiety. ${ }^{15}$ The debate between Clavijero and his opponents, then, for him also involved the defense of Catholicism and of the Spanish world as a bulwark of the Roman church against the attacks of Protestants, deists, and atheists. Notwithstanding his rejection of the secularism of his foes, Clavijero stressed the compatibility of Catholicism with the agenda of the Enlightenment. Although the Bible was an important source for him, he did not therefore renounce the rigorous application of reason or resort readily to supernatural explanations, which he observed 'are not agreeable in the century in which we live. ${ }^{\prime 16} \mathrm{~A}$ consciousness of constituting part of a new era in which empirical observation and inductive reasoning counted for more than revealed and conjectural knowledge led him to reject Saint Augustine of Hippo's claim regarding the intervention of the angels to explain the presence of Old World animals in the Western Hemisphere. Clavijero affirmed that he would only accept the possibility of the angels transporting the animals when all other possible explanations had been discarded as improbable. ${ }^{17}$

This distancing from supernatural explanations also led Clavijero to deny that the devil was an important actor in the ancient history of the

14 Clavijero, 423.

15 Ibid., 422.

16 Ibid., 435.

17 Ibid. 
New World, thus breaking with an historiographical tradition that had dominated the received understanding of Prehispanic culture, above all with respect to its religiosity. ${ }^{18}$ Clavijero argued that

the good historians of the sixteenth century and those who since have copied them took as indubitable the continuous and familiar commerce of the demon with all the idolatrous nations of the New World, and they hardly mentioned any event in which they did not present him as the principal actor. However, although it is certain that the malignity of those spirits is exerted when they can do evil to men and that sometimes they have presented themselves in visible form to seduce men, especially to those who have not yet entered into the bosom of the Church through their regeneration, it is not therefore credible that these representations were so frequent, nor [the demon's] commerce so free with those nations as is supposed by the historians; because God, who watches with loving providence over his creatures, does not permit those capital enemies of the human race so much liberty to harm. ${ }^{19}$

A religion based on human sacrifice such as that of the Mexica of the fifteenth and early sixteenth centuries, though unacceptable, was explicable to Clavijero in terms of material causes. In his 'Eighth Dissertation,' Clavijero proposed that 'the system of natural religion depends principally on the idea held of the divinity.' However, abandoned to its own understanding, the human spirit was inclined to excesses. Indeed, '[i]f the most serious commerce of religion is confined to human reason,' argued Clavijero, 'the greatest absurdities present themselves to our understanding as true dogmas, and the worship owed to the Supreme Being will be defective because of its impiety or excessive because of its superstition,' as could be observed among ancient Americans or contemporary Europeans. ${ }^{20}$ Although Clavijero did not demonize Prehispanic beliefs, he nonetheless condemned them as superstitions. He did not agree with historians and theologians who had proposed an early Prehispanic evangelization of America whose message had become distorted with the passage of time, nor did he find acceptable efforts to

18 'Perhaps Clavigero's single most important achievement,' claims Fernando Cervantes, 'was to exorcise the devil from his patria's past, to liberate the pre-Hispanic world from the nagging interpretative burden of Acosta and Torquemada' (Cervantes, The Devil in the New World [New Haven: Yale University Press, 1994], 149).

19 Clavijero, 66.

20 Ibid., 571, 574. 
understand indigenous American divinities and rites as fundamentally Christian despite their pagan appearances. ${ }^{21}$

The narration of the Conquest, an aspect of Clavijero's work that has heretofore received little scholarly attention, played an important role in his rebuttal of the innate weakness and cowardice attributed to the indigenous population. A respectful revisionist, Clavijero was faithful to the historiographical traditions of his 'patria,' New Spain, in including an account of the Conquest in the Historia. Like the Franciscan Bernardino de Sahagún, whose Historia general de las cosas de la Nueva España of 1575 is the oldest precedent for Clavijero's project of offering a comprehensive analysis of Mexican culture and geography, the Jesuit was persuaded that any reflection on Prehispanic societies would be incomplete if it did not include an exploration of how they came to be subordinated to the Spanish invaders. What distinguished Clavijero's history of the Conquest from its many predecessors was not only the variety of sources consulted, but also his attempt to present the events from the perspective of the Amerindians as well as from that of the Spanish. His narrative was furnished with a sustained critical apparatus, providing footnotes in which he discussed and evaluated various versions of key episodes. He prefaced the Historia with a critical bibliography of iconographic as well as textual primary sources in Nahua and Spanish which continues to be useful to researchers. ${ }^{22}$

Though Sahagún, like Clavijero, has been celebrated for anticipating modern approaches to inquiry, both understood the Conquest in providentialist terms. At an early stage of his narration of the Conquest, Clavijero offered a declaration of faith which foreshadowed his final judgement on the downfall of Moctezuma's reign:

There is no doubt that ... on many occasions that will be seen in this history, Moctezuma could have rid himself easily of those few foreigners towards whom

21 See Brading, 459-62.

22 Clavijero organized this annotated bibliography, 'Noticia de los escritores de la historia Antigua de México,' by centuries; particular attention was devoted to collections of 'pinturas' by sixteenth-century indigenous historians (Ibid., xxv-xxxvii). An antecedent to the 'Noticia' was Juan José de Eguiara y Eguren's 1755 Biblioteca mexicana, considered by Cañizares-Esguerra as a work of 'patriotic epistemology.' See Cañizares-Esguerra, 210-3. For Brading, the Biblioteca 'celebrated the emergence of a Mexican tradition of inquiry into Indian history and hieroglyphs.' See Brading, 388-90 and Anthony Higgins, Constructing the Criollo Archive: Subjects of Knowledge in the Bibliotheca Mexicana and the Rusticatio Mexicana (West Lafayette: Purdue University Press, 2000). 
he had so much distrust; but God protected them as instruments of his justice, using their arms to avenge the superstition, cruelty, and other crimes with which those nations had for so long provoked his indignation. We do not pretend here to justify the intentions and behaviour of the conquistadores, but we cannot but recognize in the events of the Conquest, despite our incredulity, the hand of God that disposed the things of that empire towards its ruin and served himself of the errors of mankind for the high goals of his Providence. ${ }^{23}$

Counterbalancing the folly of humankind, providence appeared at key moments in the narrative. Clavijero did not ascribe the Conquest to the courage or resourcefulness of the Spaniards, but rather to divine intervention. ${ }^{24}$

During the colonial period, recounting the Conquest was a discursive strategy oriented towards inscribing one's concerns symbolically and concretely in the sociopolitical context. For soldiers who had participated in the invasion such as Bernal Díaz del Castillo, Francisco de Aguilar, and Andrés de Tapia as for descendants of the indigenous noble allies of Hernán Cortés such as Fernando de Alva Ixtlilxóchitl and Domingo de San Antón Muñón Chimalpahin Cuauhtlehuanitzin, to narrate the Conquest was to clarify who was responsible for shaping it. Such narratives often served to argue for the value of the contribution of the author or his family, with the expectation that a better informed and grateful king would reward this service. Pragmatic considerations also motivated several of the accounts of the Conquest written by clerics. For the Dominican Bartolomé de las Casas, the Conquest served in his Brevísima relación de la destrucción de las Indias as evidence of the brutality of the conquistadores, and thus contributed to the curtailment of their power by the crown. For Franciscans such as Toribio de Benavente ('Motolinía'), Jerónimo de Mendieta, Sahagún, and Diego Valadés, presenting Cortés' expedition as providential and associating the evangelizing efforts of their order with the enterprise of the conquistador served to assert the primacy of the Franciscans in the dissemination of the gospel in New Spain. Mendieta ascribed the Conquest an important role in the Counter Reformation without concerning himself overly with precision,

23 Clavijero, 305.

24 Thus Fernando Cervantes goes too far in affirming that in sharp contrast to all previous accounts of ancient Mexico, the Historia Antigua adopted an unmistakably secular historical approach' (Cervantes, 149). 
contending that Martin Luther and Cortés were born in the same year. 'Here one needs to reflect at length,' suggested Mendieta,

how as without a doubt God specially chose and took as an instrument this valiant captain Don Hernando Cortés, so that through him the door would be opened and a path broken for the preachers of his Gospel in this new world, where the Catholic church was restored and recompensed by the conversion of many souls for the loss and great harm that the damned Luther was to cause in the same season and time in the old Christendom. ${ }^{25}$

For Mendieta, Spanish imperialism was justified by its consequent wider dissemination of the Christian message. His use of providence served to underline the continuity between the military and the spiritual conquest.

Conscious of the extent to which the various histories of the Conquest reflected the political priorities of their authors, Clavijero declared: 'I distance myself equally from the panegyric of Solís and the invective of the most illustrious ... las Casas, because I do not want to adulate my compatriots, nor calumniate them.' Antonio de Solís, Clavijero explained in a note, wrote to 'praise his hero' Cortés; las Casas wrote 'transported by pious zeal in favor of the Indians.' Clavijero argued that 'I leave the events in that degree of certainty or verisimilitude in which I encounter them; when I cannot be certain regarding any event because of the disagreement of authors, as in the death of King Moctezuma, I present the diverse opinions fairly, but without omitting the conjectures dictated by honest reason. ${ }^{26}$ This resolution of the discordance among the multiple narratives of the Conquest reflected Clavijero's enlightened patriotism, which motivated him to overcome the factionalism of his panoply of sources to better respond to a common detractor. For the first time the Conquest was presented in a manner in which the actions of the Amerindians as well as those of the Spaniards were presented as consistent with the logic of their cultures. Clavijero's providentialism resolved the textual tension created by this double perspective. Thus, regarding Moctezuma's consent to becoming the prisoner of Cortés, Clavijero concluded:

25 Mendieta, Historia eclesiástica indiana, ed. Antonio Rubial García (México: Cien de México, 1997), 1:305.

26 Clavijero, xxii. 
I know well that the readers will feel the same irritation as I do writing when they read and reflect upon this extraordinary event; but it is necessary to praise in this and other events of our history the most high counsels of Divine Providence, which took the Spanish as instruments of its justice and of its mercy towards those nations, punishing in some superstition and cruelty, and illuminating the others with the light of the Gospel. ${ }^{27}$

The Spanish as well as indigenous accounts of the Conquest offered partial visions of its constituent events and conflicting interpretations of the motives of the participants. Thus there was no consensus in the understanding of key incidents such as the death of Moctezuma and the killings at Cholula. The Spanish accounts were confused and careless in their use of Nahua names: the indigenous comrades-in-arms of the conquistadores usually appeared as an anonymous mass described as 'allies' or 'friends,' with little effort made to depict individuals or differentiate ethnicities. In indigenous versions ethnic pride could also lead to the elision of other ethnic groups; thus in the anonymous Códice Ramírez the extensive Tlaxcalan involvement in the siege of Tenochtitlán was overlooked, and the successful conclusion of that long and arduous campaign was attributed solely to the Spanish and their Texcocano allies. ${ }^{28}$ For Clavijero, the issue of indigenous participation in the Conquest was a central concern, given the inclination of his European contemporaries to ascribe feebleness and pusillanimity to the inhabitants of the New World. To provide evidence of determined resistance as well as active and effective collaboration with the conquerors was crucial to demonstrating the equal capacities of Americans and Europeans.

Disregarding the exaggerations of unreliable texts but marshalling information corroborated by multiple sources, a distinctive feature of Clavijero's narrative was the respect he accorded to the indigenous participants, exceptional for an historian of the Conquest who was not Amerindian. Thus Clavijero told of the recrimination that Cacamatzin, lord of Acolhuacán, directed at Moctezuma, already a prisoner of Cortés. Impatient with the authority that the Spanish had attained in the court of México, and ashamed of the miserable situation of his uncle, King Moctezuma, Cacamatzin sent him a message urging him to be mindful that he was a lord and should cease to be the slave of 
foreigners. ${ }^{29}$ According to Clavijero, Cacamatzin waxed indignant at what he perceived as the cowardice of Moctezuma: Cacamatzin protested

[t]hat since [Moctezuma] was not motivated by zeal for the Mexican religion and the Acolhúa gods, which those infamous [Spaniards] had insulted and shown contempt, nor the glory and fame of their predecessors, obscured and contaminated by his cowardice, he [Cacamatzin] would come to the aid of his religion, revenge his gods, conserve the kingdom, recuperate reputation and liberty for himself and all his nation; that to this end he would go ... to México, but not with his hands on his breast, but holding the sword to erase with the blood of the Spanish the opprobrium of the Mexicans. ${ }^{30}$

Clavijero criticized the motives of the conquistadores as well as Aztec religiosity. Thus, of the refusal of the inhabitants of Tenochtitlán to surrender their city after three months under siege for fear of their vengeful gods, Clavijero observed that, if in making this decision,

sentiments of honor and love of patria, and of their own liberty had more impact than superstition, it would not have been so reprehensible; for although they could have foreseen the inevitability of their ruin if the war continued, they did not have hope of better fortune with peace. The experience of the preceding events had made them suspect of the advantages that [the Spanish] promised; and thus it should have seemed to them more in keeping with the concept of honor, to die with arms in hand in defense of their patria and of their liberty, than to prostitute their patria to the ambition of those foreigners and subject themselves with their surrender to a sad and miserable servitude. ${ }^{31}$

If in Clavijero's Historia the account of the Conquest was assigned the rhetorical role of narratio, demonstrating through a recounting of events that the fall of Tenochtitlán was not so rapid or so easily accomplished as many had claimed, and thus that the Conquest could not be cited as evidence of the debility and cowardice of the indigenous inhabitants of the New World, the episode also raised for him the tension between the free will of the individual and providential predetermination. With the backdrop of the growing impiety of Europe, Clavijero in again recount-

29 Clavijero, 348.

30 Ibid., 349.

31 Ibid., 408. 
ing the tale of the Conquest was not only challenging the assertion that America was generally inferior, but also reaffirming his faith in the face of widespread dismissal of the religious justification for Spanish imperialism.

However, in contrast to the soldiers, friars, and indigenous writers who included in their accounts of the Conquest the arrival and imposition of Christianity, pointing to the interpenetration of the military and spiritual conquests, Clavijero ended his narrative with the fall of Tenochtitlán. He closed the chapters of the Historia dedicated to the fall of the Mexica empire with a damning indictment of New Spain's indigenous peoples. He argued that

the Mexicans with all the other nations who aided in realizing their downfall, despite the Christian and prudent laws of the Catholic Monarchs, have been abandoned to poverty, oppression, and to contempt, not only of the Spanish, but also of the most vile African slaves and of their infamous descendants, God avenging on the miserable posterity of these nations the cruelty, injustice and superstition of their ancestors. A funereal example of Divine Justice and of the instability of the kingdoms of the earth. ${ }^{32}$

The largest component of New Spain's population was thus presented as condemned to a merited state of abjection for what Clavijero considered the errors of its ancestors. He saw their calamity as an act of God, but not as arising from any intrinsic inferiority of the New World; moreover, he was troubled by the humiliation of the Aztecs and their descendants, claiming that they occupied a lower rank in New Spain's racially statified society than that assigned to African slaves.

In the Historia general de la América Septentrional, Lorenzo Boturini Benaduci praised fellow Italian Vico as the 'eagle and immortal honour of the delightful Pertenope,' explains that Vico's approach was 'a new system of natural rights of people based on the two pillars of Providence and free will. ${ }^{\prime 3}$ Clavijero, explained David Anthony Brading, 'made nothing' of Boturini's - and thus of Vico's - scheme of human devel-

33 Lorenzo Boturini Benaduci, Historia general de la América Septentrional, ed. Manuel Ballesteros Gaibrois (México: Universidad Nacional Autónoma de México, 1990), 18. According to Manuel Ballesteros Gaibrois, Vico's work was ill-regarded by more conservative Catholics (xlviii). 
opment, their theory of the three ages of humanity. ${ }^{34}$ However, Clavijero consulted Boturini's observations extensively, and Elías Trabulse has suggested that Clavijero's understanding of providence was indebted to that of Vico. ${ }^{35}$ Although Clavijero did not cite Vico in his Historia, he probably had an opportunity to read the New Science, as this work was well-known in the Papal States. ${ }^{36}$ Vico affirmed the complementarity of human agency and providence, contending that ' $[t]$ he world of nations is in fact a human creation,' but that 'without doubt this world was created by the mind of providence, which is often different, sometimes contrary, and always superior to the particular goals which people have set for themselves. ${ }^{37}$ Providence worked through the individual decisions of humankind; thus, Vico explained, 'providence uses people's limited goals as a means of attaining greater ones.' Vico saw conquests as one of the 'remedies' that providence could provide against 'great civil maladies.' 'When people are corrupt,' argued Vico,

they are natural slaves to unbridled passions such as luxury, fastidiousness, avarice, envy, pride, and ostentation. And in seeking the pleasures of their dissolute life, they relapse into all the vices characteristic of ignoble slaves: lying, trickery, theft, cowardice, and hypocrisy. Hence, providence causes them to become real slaves under the natural law which derives from the nature of nations. Such people are subjugated to superior nations which conquer them by arms and then protect them as subject provinces. ${ }^{38}$

Like Vico, Clavijero saw the calamity of a people as punishment for sinful actions, not as the consequence of a crippling environment. Clavijero bemoaned the humiliation of the Mexica, but nonetheless envisioned them as justly rewarded for their 'cruelty, injustice and superstition.'

Clavijero, then, not only chided de Pauw and other European intellectuals for failing to demonstrate the objectivity they claim to esteem so

34 Brading, 461. Brading noted that Vico 'quietly excised the Devil from his naturalistic account of the origin of pagan religion and society' (Ibid., 384).

35 See Trabulse, 'Clavigero: Historiador de la Ilustración mexicana,' in Martínez Rosales, 52-57.

36 Ibid., 52. The disfavour with which this work was regarded by the Church may explain Clavijero's silence regarding his debt to Vico.

37 Vico, New Science, trans. David Marsh (London: Penguin, 2001), 489.

38 Ibid., 487-8. 
greatly, but also argued that the Franciscan interpretation of the Prehispanic American past fell short by departing from a rational explanation of Prehispanic religiosity. Nonetheless, Clavijero's vision of the New World, like that of the Franciscans, was ultimately also shaped by his commitment to beliefs that lie beyond empirical validation. Thus the enlightened Christianity of Clavijero in the last analysis, to borrow the evocative formulation of Octavio Paz, made of faith a trap of reason. ${ }^{39}$

BEATRIZ DE ALBA-KOCH

University of Victoria

39 Paz, Sor Juana Inés de la Cruz o Las trampas de la fe (México: Fondo de Cultura Económica, 1982). 